\title{
Are Analysts Overoptimistic about the Prospects of Sin Firms?
}

\author{
Jin Zhang ${ }^{1}$ \& Haeyoung Shin ${ }^{2}$ \\ ${ }^{1}$ College of Business Administration, California State University, Sacramento, USA \\ ${ }^{2}$ School of Business, University of Houston - Clear Lake, USA \\ Correspondence: Jin Zhang, College of Business Administration, California State University, Sacramento, USA.
}

Received: August 30, 2017

Accepted: September 14, 2017

Online Published: September 19, 2017

doi:10.5430/ijfr.v8n4p99

URL: https://doi.org/10.5430/ijfr.v8n4p99

\begin{abstract}
We investigate the association between the bias and accuracy of consensus analysts' earnings forecasts and whether a firm is a sin firm or not. We measure analyst forecast bias as the difference between the consensus earnings forecast and the actual earnings, scaled by the stock price. We measure analyst forecast accuracy as the negative of the absolute value of the difference between the firms' forecasted and actual earnings, scaled by the stock price. We find a positive association between the level of forecast optimism and sin firm membership. We find a negative association between the level of forecast accuracy and sin firm membership. Overall, these results imply that analysts tend to issue over-optimistic and less accurate earnings forecasts on sin firms.
\end{abstract}

Keywords: analysts’ optimism, sin firms, analysts' forecast accuracy

\section{Introduction}

Social norms are important in shaping economic behavior and market outcomes. Sustainable and Socially Responsible Investment (SRI) has continued to grow at a faster pace than conventional investment assets, and is now quite popular in financial markets. Since 2005, SRI assets have increased more than 34\% while the broader universe of professionally managed assets has increased only 3\% (Social Investment Forum, 2010). At the beginning of 2010, the nearly one out of every eight dollars under professional management in the United States -approximately 12\% in total assets-was involved in some strategy of socially responsible investing (Social Investment Forum, 2010). In general, socially responsible investors favor corporate practices that promote environmental, consumer protection, and human rights and avoid businesses involved in alcohol, tobacco, gambling, weapons, or the military (Social Investment Forum, 2010). Meanwhile, a large number of information intermediaries have emerged with the purpose of rating and ranking companies across several dimensions of environmental, social and corporate governance performance. Sin stocks (firms engaging in activities related to tobacco, gambling and alcohol) are most often negatively screened stocks by socially responsible investors and information intermediaries due to social norms.

The neglect effect of sin stocks has been examined by previous literature. For instance, Hong and Kacperczyk (2009) document sin stocks earn abnormal returns after accounting for market beta, book to market, size and momentum. They attribute the abnormal returns to a neglect effect due to investors' social preference. They also find that sin stocks have lower level of institutional ownership, and fewer analysts following. Kim and Venkatachalam (2011) investigate financial reporting quality of sin stocks. They find that financial reporting of sin firms is superior along two dimensions: predictability of earnings for future cash flows and timely loss recognition. Zhang (2012) find a negative association between sin firm membership and the magnitude of absolute discretionary accruals, where discretionary accruals are adjusted for firm performance, implying that sin firms are less likely to manage their earnings, specifically, less likely to engage in income-increasing earnings management.

This paper examines the association between the bias and accuracy of consensus analysts' earnings forecasts and whether a firm is a sin firm or not. Biases in analysts' earnings forecasts are widely documented in the accounting and finance area. The nature and causes of analysts' forecast bias has been the subject of research for at least three decades. Earlier research finds that in aggregate, analysts' forecasts are optimistically biased (e.g. Stickel (1991), Francis and Phibrick (1993)). Recent research indicates that managers do not uniformly prefer optimistic earnings forecasts. Abarbanell and Lehavy (2003), hereafter referred as AL examine the properties of analysts' earnings forecasts, and provide insights into the vast seemingly mixed results on analysts' forecast bias (see AL for an excellent summary). In particular, AL document two distinct domains in the empirical distribution of analyst forecast errors that differentiate it 
from a typical bell-shaped normal distribution: the middle and negative tail asymmetries. The negative tail asymmetry is consistent with optimistic forecasts and the middle asymmetry is consistent with pessimistic forecasts. AL interpret their result by conjecturing that such a pattern is more likely to be caused by the earnings management rather than analysts' choice, i.e., biased earnings rather than biased forecast.

We investigate the association between the bias and accuracy of consensus analysts' earnings forecasts and whether a firm is a sin firm or not. Sin stocks are stocks in the following industries: alcoholic beverages, tobacco and gaming. We follow the method similar with Hong and Kacperczyk (2009) to identify sin stocks. First, we include all firms in SIC codes 2100-2199 as part of tobacco group and firms in the SIC codes 2080-2085 as firms in the alcohol group. Second, we use the NAICS classification to identify stocks in the gaming industry, i.e., stocks in the NAICS codes of $7132,71312,713210,713290,72112$, and 721120 . We include in the sample all firm-quarter observations spanning from 2000 to 2015 for which required data are available on Compustat.

We measure analyst forecast bias as the difference between the consensus earnings forecast and the actual earnings, scaled by the stock price. We measure analyst forecast accuracy based on the negative of absolute value of the difference between the firms' forecasted and actual earnings, scaled by the stock price. Multiplying the absolute forecast error by $(-1)$ give a measure that increases with greater forecast accuracy. The ACCURACY values are negative by construction (see Lang, Lins and Miller 2003)).

We provide evidences on the association between analyst forecast and sin firm membership. We find a positive association between the level of forecast optimism and sin firm membership. We find a negative association between the level of forecast accuracy and sin firm membership. Overall, these results imply that analysts tend to issue over-optimistic and less accurate earnings forecasts on sin firms.

The rest of paper is organized as follows. Section 2 introduces the related research and develop the main hypotheses. Section 3 describes the sample and methodology. Section 4 presents empirical evidence, and Section 5 concludes the paper.

\section{Hypotheses Development}

It has been well documented that analysts' earnings forecasts exhibit overoptimism (e.g., Abarbanell and Bernard (1992), Easterwood and Nutt (1999)). Two (non-competing) explanations have emerged as to why analysts issue more optimistic forecasts. The first explanation follows the strategic bias model (Francis and Philbrick (1993); Das, Levine, and Sivaramakrishnan (1998); Lim (2001); Mest and Plummer (2003)), in which analysts have an incentive to issue favorable earnings estimates to maintain their relationship with management. Sustaining a good relationship with corporate executives is critical for analysts competing to obtain access to certain information witheld by management. In response to high earnings uncertainty, the strategic bias view suggests that analysts' earnings estimates would be upward biased. The second explanation follows the selection bias model (McNichols and O'Brien (1997); Hayes and Levine (2000); Diether, Malloy, and Scherbina (2002)), which argues that because analysts are attracted to make forecasts when a firm's earnings reach above a certain threshold (self-censoring), forecast estimates tend to be optimistic. Furthermore, Diether et al. (2002) show that the forecast optimism resulting from self-censoring is stronger when earnings uncertainty measured by the variance of actual earnings is higher.

This paper investigates the impact of corporate social responsibility on analyst forecasts. Sin stocks (firms engaging in activities related to tobacco, gambling and alcohol) are most often negatively screened stocks by socially responsible investors and information intermediaries due to social norms. We expect that forecast biases are different for sin firms and non-sin firms, as sin firms are less socially responsible firms, and analysts may have social preferences when they evaluate firms

On one hand, Hong and Kacperczyk (2009) provide evidence on the potential downside of having an investment philosophy that adheres to social norms by focusing their attention on the investment environment of sin stocks. They document that sin firms have lower institutional ownership and analyst coverage, consistent with the notion that such stocks are eschewed by an important group of capital market participants. Hong and Kacperczyk (2009) and Kim and Venkatachalam (2011) document that these sin firms behave like value stocks and outperform the market after controlling for factors that determine expected returns. Collectively, their evidence suggests that sin stocks are both neglected and undervalued. It is plausible that analysts issue more optimistic forecasts on undervalued sin stocks. Moreover, previous literatures (Francis and Philbrick (1993); Das, Levine, and Sivaramakrishnan (1998);

Lim (2001); Mest and Plummer (2003)) document that analysts have an incentive to issue favorable earnings estimates to maintain their relationship with management. Sin firms, which have lower institutional ownership and analyst 
coverage, have an incentive to provide more private information to analysts. The analysts would be relatively optimistic about the future profitability of sin firms.

On the other hand, Lim's (2001) model of rational bias posits that analysts issue more favorable forecasts for firms with less predictable earnings. Consistent with Lim's (2001) prediction, Das et al. (1998) provide empirical evidence that forecasts are more optimistically biased when earnings are less predictable. Sin firms report higher quality accounting information to attract sophisticated market participants, i.e., institutional investors and analysts (Kim and Venkatachalam, 2011). It is of a less concern to sin firms that managing earnings to meet or beat analyst forecast due to the neglect effect of sin firms (Zhang 2012). Since analysts issue optimistic earnings forecast when earnings are uncertain, sin firms, with higher quality accounting information, may have less optimistic earnings forecasts, compared with non-sin firms. Moreover, corporate social responsibility (CSR) becomes favorably evaluated by sell-side analysts in recent years (Ioannou and Serafeim (2015)). It is plausible that analysts issue less optimistic forecasts on sin firms, which are highly social irresponsible firms.

Thus, it is an empirical question on whether analysts are relatively more optimistic or less optimistic on the future of sin firms. The following hypotheses summarize my expectations:

H1a. Analysts are relatively more optimistic about the future of sin firms.

H1b. Analysts are relatively less optimistic about the future of sin firms.

\subsection{Contribution}

This paper contributes the literature by exploring the impact of social norms on the capital market and more specifically, by understanding the underlying sociological processes that determine how these analysts perceive and evaluate the firms with poor corporate social responsibility, i.e., sin firms. Moreover, this paper contributes analysts' bias literature by showing the significant difference of forecast bias between sin firms and non-sin firms.

\section{Data and Research Design}

\subsection{Sample Selection}

The first objective in the sample selection process is to identify a set of sin stocks. Sin stocks are stocks in the following industries: alcoholic beverages, tobacco and gaming. We follow the method similar with Hong and Kacperczyk (2009) to identify sin stocks. First, we include all firms in SIC codes 2100-2199 as part of tobacco group and firms in the SIC codes 2080-2085 as firms in the alcohol group. Second, we use the NAICS classification to identify stocks in the gaming industry, i.e., stocks in the NAICS codes of 7132, 71312, 713210, 713290, 72112, and 721120. We obtain all financial statements information from the Compustat database. We include in the sample all firm-quarter observations spanning from 2000 to 2015 for which required data are available on Compustat.

Table 1 provides a year by year look at my data set of sin stocks beginning in 2000 and ending at 2015. There is a total of 408 sin companies, comprised of 50 distinct tobacco companies, 108 distinct alcohol companies and 250 distinct gaming companies. Our sample is less than Hong and Kacperczyk (2009)'s sample since they use Compustat segment data to include firms that have segments operating in any these SIC or NAICS groups. We only include the firms whose main businesses are engaging in alcoholic beverages, tobacco and gaming. There are not a lot of sin firms related to all other firms. The number of sin stocks doesn't not change a lot in 2010's.

Table 1. Number of sin firms by year

\begin{tabular}{lllll}
\hline Year & All & Tobacco & Alcohol & Gaming \\
\hline 2000 & 21 & 1 & 8 & 12 \\
2001 & 22 & 1 & 7 & 14 \\
2002 & 22 & 1 & 6 & 15 \\
2003 & 23 & 2 & 5 & 16 \\
2004 & 27 & 3 & 6 & 18 \\
2005 & 29 & 3 & 6 & 20 \\
2006 & 29 & 3 & 7 & 19 \\
2007 & 28 & 3 & 7 & 18 \\
2008 & 30 & 5 & 7 & 16 \\
\hline
\end{tabular}




\begin{tabular}{lllll}
\hline 2009 & 25 & 4 & 5 & 16 \\
2010 & 26 & 4 & 6 & 16 \\
2011 & 25 & 4 & 7 & 16 \\
2012 & 26 & 4 & 8 & 14 \\
2013 & 25 & 4 & 7 & 12 \\
2014 & 27 & 4 & 9 & 12 \\
2015 & 23 & 4 & 7 & 12 \\
\hline Total & 408 & 50 & 108 & 250 \\
\hline
\end{tabular}

Note: This table reports year by year the number of sin stocks that fall into three sub-groups of tobacco, alcohol and gaming. The data span the period of 2000-2015.

\subsection{Main Variables}

We measure bias (BIAS) consistent with prior research (Duru and Reeb (2002); Lang, Lins and Miller (2003); Herrmann, Hope and Thomas (2008)). The variable BIAS is the difference between the latest consensus earnings forecast and the actual earnings, scaled by the stock price.

$$
B I A S_{t}(\text { OPTIMISM })=\frac{F O R E C A S T_{t}-A C T U A L_{t}}{P R I C E_{t-1}}
$$

where FORECAST ${ }_{t}$ is the latest consensus earnings forecast of the period t. ACTUAL $L_{t}$ is the actual earnings per share before extraordinary items of the period $t$. Price $\mathrm{t}_{\mathrm{t}-1}$ is the stock price at the time of $\mathrm{t}-1$. A positive (negative) BIAS indicates analyst optimism (pessimism). Forecast optimism increases as BIAS becomes larger, while optimism decreases as BIAS becomes smaller.

We measure forecast Accuracy based on absolute value of the difference between the firms' forecasted and actual earnings, divided by stock price at time $t$.

$$
A C C U R A C Y_{t}=-\left|\frac{F O R E C A S T_{t}-A C T U A L_{t}}{P R I C E_{t-1}}\right|
$$

where ACCURACY ${ }_{t}$ is the negative of the absolute forecast error at time $t$. Multiplying the absolute forecast error by (-1) give a measure that increases with greater forecast accuracy. The ACCURACY values are negative by construction (see Lang, Lins and Miller 2003)). The closer the accuracy value is to zero, the more accurate the forecast.

\subsection{Empirical Models}

Consistent with Zhang, Lin and Shin (2000), we estimate the following regression to test H1(a) and H1(b):

$$
\begin{gathered}
\text { BAIS }_{\mathrm{j}, \mathrm{q}}=\alpha_{0}+\beta_{0} \text { SINFIRM }_{\mathrm{j}, \mathrm{q}}+\beta_{1} \text { ANALYSTS }_{\mathrm{j}, \mathrm{q}-1}+\beta_{2} \operatorname{DISPERSION~}_{\mathrm{j}, \mathrm{q}-1}+\beta_{3} \text { LNSIZE }_{\mathrm{j}, \mathrm{q}-1}+\beta_{4} \text { RETQ1 }_{\mathrm{j}, \mathrm{q}-1}+\beta_{5} \mathrm{UE}_{\mathrm{j}, \mathrm{q}-1}+ \\
\beta_{6} \operatorname{LOSS}_{\mathrm{j}, \mathrm{q}}+\varepsilon_{\mathrm{j}, \mathrm{q} .}
\end{gathered}
$$

BAIS is the difference between the consensus earnings forecast and the actual earnings, scaled by the stock price. SINFIRM is our main variable of interest. It equals one if the firm engages in activities related to tobacco, gambling and alcohol. A significantly positive coefficient on SINFIRM would be consistent with our H1a. A significantly negative coefficient on SINFIRM would be consistent with our H1b. We include a number of additional variables in the model to control for various factors that may confound the relationship between forecast bias and sin firm membership.

We control for the number of analysts (ANALYST) since Lys and Soo (1995) suggest that the number of analysts proxies for the intensity of competition in the market. Greater analyst following indicates greater ex ante incentives for analysts to make accurate forecasts and a better ex post information environment of the followed company. ANALYST is the number of analysts following. We also control for analyst disagreement (DISPERSION). DISPERSION is measured as standard deviation earnings forecast scaled by the stock. 
We further control for firm size (LNSIZE), as a proxy for a firm's general information environment (Atiase, 1985). In addition, various other factors potentially related to firm size (Hope, 2003). Firm size (LNSIZE) is measured as the natural log of book value of total assets at the beginning of the fiscal quarter. We also control for stock return over the previous quarter (RETQ1). RETQ1 is measured as the buy-and-hold raw return cumulated over the previous quarter.

Hayn (1995) argues that the valuation of loss firms may be different from that of profit ones because investors are more likely to exercise their liquidation option. Because the informativeness of earnings for future cash flows is weaker among loss than among profit firms analysts will have greater difficulty in forecasting the earnings of those firms. We include an indicator variable, LOSS, to control for this effect. LOSS equals one if the firm reports negative earnings in the quarter and zero otherwise. We also control for price deflated earning change (UE). UE is measured as the difference in earnings per share before extraordinary items between fiscal quarter $\mathrm{t}$ to quarter $\mathrm{t}-1$, scaled by the stock price at the beginning of quarter $t$.

We also estimate the following regression to test the association between analyst forecast accuracy and sin firm membership:

$$
\begin{aligned}
& \text { ACCURACY }_{\mathrm{j}, \mathrm{q}}=\alpha_{0}+\beta_{0} \text { SINFIRM }_{\mathrm{j}, \mathrm{q}}+\beta_{1} \text { ANALYSTS }_{\mathrm{j}, \mathrm{q}-1}+\beta_{2} \text { DISPERSION }_{\mathrm{j}, \mathrm{q}-1}+\beta_{3} \text { LNSIZE }_{\mathrm{j}, \mathrm{q}-1}+\beta_{4} \text { RETQ1 }_{\mathrm{j}, \mathrm{q}-1}+ \\
& \beta_{5} \mathrm{UE}_{\mathrm{j}, \mathrm{q}-1}+\beta_{6} \mathrm{LOSS}_{\mathrm{j}, \mathrm{q}}+\varepsilon_{\mathrm{j}, \mathrm{q}}
\end{aligned}
$$

ACCURACY $Y_{t}$ is the negative of the absolute forecast error at time t. Multiplying the absolute forecast error by (-1) give a measure that increases with greater forecast accuracy. SINFIRM is our main variable of interest. It equals one if the firm engages in activities related to tobacco, gambling and alcohol. A significantly positive coefficient on SINFIRM would be consistent with prediction that analysts issue more accurate earnings forecasts on sin firms. A significantly negative coefficient on SINFIRM would be consistent with prediction that analysts issue less accurate earnings forecasts on sin firms. We include the same control variables in the equation (3) to control for various factors that may confound the relationship between forecast accuracy and sin firm membership.

\section{Results}

Table 2 provides descriptive statistics of the variables used in the empirical analysis for both sin firms and all other firms. Sin stocks are larger and are characterized by higher return (mean of 0.034 for sin firms vs. 0.025 for all other firms, median of 0.024 for sin firms vs. 0.014 for all other firms), consistent with the conjecture that sin stocks are perhaps value stocks. The number of analyst following is significantly different between sin firms and all other firms (mean of 9.530 for sin firms vs. 8.072 for all other firms, median of 9.000 for sin firms vs. 6.000 for all other firms). Bias is larger for sin firms (mean of 0.182 for sin firms vs. 0.138 for all other firms), although the difference is not statistically significant $(\mathrm{t}=-1.05)$. Many of the control variables are significantly different between sin and non-sin firms. Thus it is important to control these variables to draw proper conclusions about relation between analyst optimism and whether a firm is a sin firm or not.

Table 2. Descriptive statistics

Panel A: Mean

\begin{tabular}{llll}
\hline & & \multicolumn{2}{c}{$2010-2015$} \\
\hline & Sin firms & All other firms & Difference \\
& $(1)$ & $(2)$ & t-stat $(2-1)$ \\
\hline BIAS $(\%)$ & 0.182 & 0.138 & -1.05 \\
ACCURACY $(\%)$ & -0.536 & -0.701 & $-3.34^{* * *}$ \\
ANALYSTS & 9.530 & 8.072 & $-8.95^{* * *}$ \\
DISPERSION & 0.196 & 0.266 & $6.86^{* * *}$ \\
LNSIZE & 7.803 & 7.016 & $-17.67^{* * *}$ \\
RETQ1 & 0.034 & 0.025 & -1.36 \\
UE & 0.001 & 0.001 & -0.01 \\
LOSS & 0.110 & 0.184 & $7.41^{* * * *}$ \\
\hline \# of OBS & 1,494 & 155,063 & \\
\hline
\end{tabular}


Panel B: Median

\begin{tabular}{llll}
\hline & & & 2010-2015 \\
\hline & Sin firms & All other firms & Difference \\
& $(1)$ & $(2)$ & Z-stat $(2-1)$ \\
\hline BIAS (\%) & 0.000 & -0.023 & $-4.11 * * *$ \\
ACCURACY $(\%)$ & -0.124 & -0.019 & $-7.25 * * *$ \\
ANALYSTS & 9.000 & 6.000 & $-12.17 * * *$ \\
DISPERSION & 0.081 & 0.102 & $6.73 * * *$ \\
LNSIZE & 7.928 & 6.896 & $-14.58^{* * *}$ \\
RETQ1 & 0.024 & 0.014 & $-2.20 * *$ \\
UE & 0.000 & 0.000 & $1.66 *$ \\
LOSS & 0.000 & 0.000 & $7.41 * * *$ \\
\hline \# of OBS & 1,494 & 155,063 & \\
\hline
\end{tabular}

Notes: $* * *, * *$, and $*$ indicate significance at the $1 \%, 5 \%$, and $10 \%$ level, respectively. SINFIRM equals one if the firm engages in activities related to tobacco, gambling and alcohol. BIAS is the difference between the consensus earnings forecast and the actual earnings, scaled by the stock price. ACCURACY is the negative of the absolute forecast error, scaled by the stock price. ANALYSTS is the number of analysts following. DISPERSION is standard deviation earnings forecast scaled by the stock. LNSIZE is measured as the natural log of market value of the firm at the beginning of the fiscal quarter. UE is the difference in earnings per share before extraordinary items between fiscal quarter $\mathrm{t}$ and quarter $\mathrm{t}-1$, scaled by the stock price at the ending of quarter $\mathrm{t}-1$. RETQ1 is the buy-and-hold raw return cumulated over the previous quarter. LOSS equal to 1 for observations with negative earning, zero otherwise.

Table 3 presents the regression estimates of Equation (3). The coefficient on SINFIRM is positive and significant in the BIAS model $(0.157, \mathrm{t}=3.96)$. The coefficients on the control variables, whenever significant, are consistent with the signs predicted by previous studies. Overall, the results suggest that there is a positive association between analyst optimism and whether this firm is a sin firm.

Table 3. Sin firms and analyst forecast bias, 2000-2015

\begin{tabular}{|c|c|c|}
\hline & \multicolumn{2}{|c|}{ Dependent Var. =BIAS } \\
\hline & Coeff. & t-stat. \\
\hline Intercept & -0.061 & $-3.05 * * *$ \\
\hline SINFIRM & 0.157 & $3.96 * * *$ \\
\hline ANALYSTS & 0.003 & $4.08 * * *$ \\
\hline DISPERSION & 0.234 & $27.73 * * *$ \\
\hline LNSIZE & -0.014 & $-4.63 * * *$ \\
\hline RETQ1 & -0.192 & $-21.46 * * *$ \\
\hline $\mathrm{UE}$ & -0.182 & $-26.15 * * *$ \\
\hline LOSS & 1.177 & $105.45 * * *$ \\
\hline Adjusted R ${ }^{2}(\%)$ & \multicolumn{2}{|c|}{11.00} \\
\hline No. of Observations & \multicolumn{2}{|c|}{156,557} \\
\hline
\end{tabular}

Notes:

1. Model: BAIS ${ }_{\mathrm{j}, \mathrm{q}}=\alpha_{0}+\beta_{0}$ SINFIRM $_{\mathrm{j}, \mathrm{q}}+\beta_{1}$ ANALYSTS $_{\mathrm{j}, \mathrm{q}-1}+\beta_{2}$ DISPERSION $_{\mathrm{j}, \mathrm{q}-1}+\beta_{3}$ LNSIZE $_{\mathrm{j}, \mathrm{q}-1}+\beta_{4}$ RETQ1 $_{\mathrm{j}, \mathrm{q}-1}+$ $\beta_{5} \mathrm{UE}_{\mathrm{j}, \mathrm{q}-1}+\beta_{6} \operatorname{LOSS}_{\mathrm{j}, \mathrm{q}}+\varepsilon_{\mathrm{j}, \mathrm{q}}$.

2. $* * *, * *$, and $*$ indicate that the estimated coefficients are statistically significant at the $1 \%, 5 \%$, and $10 \%$ level, respectively. Degree of Freedom is 156,549. 
3. SINFIRM equals one if the firm engages in activities related to tobacco, gambling and alcohol. BIAS is the difference between the consensus earnings forecast and the actual earnings, scaled by the stock price. ANALYSTS is the number of analysts following. DISPERSION is standard deviation earnings forecast scaled by the stock. LNSIZE is measured as the natural log of market value of the firm at the beginning of the fiscal quarter. UE is the difference in earnings per share before extraordinary items between fiscal quarter $t$ and quarter $t-1$, scaled by the stock price at the ending of quarter $t-1$. RETQ1 is the buy-and-hold raw return cumulated over the previous quarter. LOSS equal to 1 for observations with negative earning, zero otherwise.

Table 4 presents the regression estimates of Equation (4). The coefficient on SINFIRM is negative and significant in the ACCURACY model $(-0.095, \mathrm{t}=-2.29)$. The coefficients on the control variables, whenever significant, are consistent with the signs predicted by previous studies. Overall, the results suggest that there is a negative association between analyst forecast accuracy and whether this firm is a sin firm.

Table 4. Sin firms and analyst forecast accuracy, 2000-2015

\begin{tabular}{lcc}
\hline & \multicolumn{2}{c}{ Dependent Var. =ACCURACY } \\
\hline Intercept & Coeff. & t-stat. \\
SINFIRM & -0.994 & $-47.65 * * *$ \\
ANALYSTS & $\mathbf{- 0 . 0 9 5}$ & $\mathbf{- 2 . 2 9 * *}$ \\
DISPERSION & -0.011 & $-13.18^{* * *}$ \\
LNSIZE & -1.577 & $-179.15 * * *$ \\
RETQ1 & 0.135 & $41.53 * * *$ \\
UE & -0.098 & $-10.52 * * *$ \\
LOSS & 0.032 & $4.46 * * *$ \\
\hline Adjusted R $(\%)$ & -0.804 & $-69.02 * * *$ \\
\hline No. of Observations & & 30.42 \\
\hline
\end{tabular}

Notes:

1. Model: ACCURACY ${ }_{\mathrm{j}, \mathrm{q}}=\alpha_{0}+\beta_{0}$ SINFIRM $_{\mathrm{j}, \mathrm{q}}+\beta_{1}$ ANALYSTS $_{\mathrm{j}, \mathrm{q}-1}+\beta_{2} \operatorname{DISPERSION}_{\mathrm{j}, \mathrm{q}-1}+\beta_{3}$ LNSIZE $_{\mathrm{j}, \mathrm{q}-1}+\beta_{4}$ RETQ1 $_{\mathrm{j}, \mathrm{q}-1}+\beta_{5} \mathrm{UE}_{\mathrm{j}, \mathrm{q}-1}+\beta_{6} \mathrm{LOSS}_{\mathrm{j}, \mathrm{q}}+\varepsilon_{\mathrm{j}, \mathrm{q}}$.

2. ***, **, and * indicate that the estimated coefficients are statistically significant at the $1 \%, 5 \%$, and $10 \%$ level, respectively. Degree of Freedom is 156,549.

3. SINFIRM equals one if the firm engages in activities related to tobacco, gambling and alcohol. ACCURACY is the negative of the absolute forecast error, scaled by the stock price. ANALYSTS is the number of analysts following. DISPERSION is standard deviation earnings forecast scaled by the stock. LNSIZE is measured as the natural log of market value of the firm at the beginning of the fiscal quarter. UE is the difference in earnings per share before extraordinary items between fiscal quarter $t$ and quarter $t-1$, scaled by the stock price at the ending of quarter $\mathrm{t}-1$. RETQ1 is the buy-and-hold raw return cumulated over the previous quarter. LOSS equal to 1 for observations with negative earning, zero otherwise.

\section{Conclusions}

This paper provides evidences on the association between the bias and accuracy of consensus analysts' earnings forecasts and whether a firm is a sin firm or not. We measure analyst forecast bias as the difference between the consensus earnings forecast and the actual earnings, scaled by the stock price. we measure analyst forecast accuracy as the negative of absolute value of the difference between the firms' forecasted and actual earnings, scaled by the stock price. We find a positive association between the level of forecast optimism and sin firm membership. We find a negative association between the level of forecast accuracy and sin firm membership. Overall, these results imply that analysts tend to issue over-optimistic and less accurate earnings forecasts on sin firms. This paper contributes the literature by exploring the impact of social norms on the capital market and more specifically, by understanding the underlying sociological processes that determine how these analysts perceive and evaluate the firms with poor corporate social responsibility, i.e., sin firms. Moreover, this paper contributes analysts' bias literature by showing the significant difference of forecast bias between sin firms and non-sin firms. 


\section{References}

Abarbanell, J., \& R. Lehavy. (2003). Biased Forecasts or Biased earnings? The role of Reported Earnings in explaining Apparent Bias and Over/Underreaction on Analysts' Earning Forecasts. Journal of Accounting \& Economics, 36, 105-146. https://doi.org/10.1016/j.jacceco.2003.11.001

Abarbanell, J.S., \& V.L. Bernard. (1992). Tests of Analysts' Overreaction/Underreaction to Earnings Information as an Explanation for Anomalous Stock Price Behavior. Journal of Finance, 47, 183-198.

Atiase, R.K. (1985). Predisclosure Information, Firm Capitalization, and Security Price Behavior around Earnings Announcements. Journal of Accounting Research, 23(1), 21-36. https://doi.org/10.2307/2490905

Das, S., C.B. Levine, \& K. Sivaramakrishnan. (1998). Earnings Predictability and Bias in Analysts' Earnings Forecasts. Accounting Review, 73, 277-294.

Diether, K.B., C.J. Malloy, \& A. Scherbina. (2002). Differences of Opinion and the Cross-Section of Stock Returns. Journal of Finance, 57, 2113-2141. https://doi.org/10.1111/0022-1082.00490

Duru, A., \& D.M. Reeb. (2002). International Diversification and Analysts' Forecast Accuracy and Bias. Accounting Review, 77, 415-433. https://doi.org/10.2308/accr.2002.77.2.415

Easterwood, J.C., \& S.R. Nutt. (1999). Inefficiency in Analysts' Earnings Forecasts: Systematic Misreaction or Systematic Optimism?. Journal of Finance, 54, 1777-1797. https://doi.org/10.1111/0022-1082.00166

Francis, J., \& D. Philbrick. (1993). Analysts' Decisions as Products of a Multi-Task Environment. Journal of Accounting Research, 31, 216-230. https://doi.org/10.2307/2491271

Hayes, R.M., \& C.B. Levine. (2000). An Approach to Adjusting Analysts' Consensus Forecasts for Selection Bias. Contemporary Accounting Research, 17, 61-83. https://doi.org/10.1111/j.1911-3846.2000.tb00911.x

Hayn, C. (1995). The Information Content of Losses. Journal of Accounting and Economics, 20, 125-153.

Herrmann, D., O. Hope, \& W.B. Thomas. (2008). International Diversification and Forecast Optimism: The Effects of Reg FD. Accounting Horizons, 22(2), 179-197. https://doi.org/10.2308/acch.2008.22.2.179

Hong, H., \& M. Kacperczyk. (2009). The Price of Sin: The Effects of Social Norms on Markets. Journal of Financial Economics, 93, 15-36. https://doi.org/10.1016/j.jfineco.2008.09.001

Hope, O. (2003, May). Disclosure Practices, Enforcement of Accounting Standards, and Analysts' Forecast Accuracy: An International Study. Journal of Accounting Research, 41, 235-272. https://doi.org/10.1111/1475-679X.00102

Ioannou, L., \& G. Serafeim. (2015). The Impact of Corporate Social Responsibility on Investment Recommendations: Analysts' Perceptions and Shifting Institutional Logics. Strategic Management Journal, 36(7), 957-1114.

Kim, I., \& M.Venkatachalam. (2011). Are Sin Stocks Paying the Price for Accounting Sins. Journal of Accounting, Auditing \& Finance, 26(2), 415-442. https://doi.org/10.1177/0148558X11401222

Lang, M., K. Lins, \& D. Miller. (2003). ADRs, Analysts, and Accuracy: Does Cross Listing in the U.S. Improve a Firm's Information Environment and Increase Market Value?. Journal of Accounting Research, 41, 317-346.

Lim, T. (2001). Rationality and Analysts' Forecast Bias. Journal of Finance, 56, 369-385. https://doi.org/10.1111/0022-1082.00329

Lys, T., \& L. Soo. (1995). Analysts' Forecast Precision as A Response to Competition. Journal of Accounting, Auditing and Finance, 10, 751-765. https://doi.org/10.1177/0148558X9501000404

McNichols, M., \& P. O'Brien. (1997). Self-Selection and Analyst Coverage. Journal of Accounting Research, 35, 167-199. https://doi.org/10.2307/2491460

Mest, D.P., \& E. Plummer. (2003). Analysts' Rationality and Forecast Bias: Evidence from Sales Forecasts. Review of Quantitative Finance and Accounting, 21, 103-122. https://doi.org/10.1023/A:1024841531461

Social Investment Forum. (2011). 2010 Report on Socially Responsible Investing Trends in the United States. Retrieved from http://ussif.org/resources/research/documents/2010TrendsES.pdf

Stickel, S. E. (1991). Common Stock Retums Surrounding Earnings Forecast Revisions: More Puzzling Evidence. Accounting Review, 66(2), 402-16.

Zhang, J, E. Lin, \& H. Shin. (2010). S\&P 500 Index Inclusions and Analysts' Forecast Optimism. The Journal of Investing, Winter, 50-57. https://doi.org/10.3905/joi.2010.19.4.050

Zhang, J. (2012). Are Sin Firms Less Likely To Manage Their Earnings?. Theortical Accounting Research, Fall, 54-72. 